from cohort to mass practice in the system of vocational education and, notwithstanding certain narrowing of the receipt categories has, nowadays, become the core of the traditions of social work and its provision. Preserved and acquired principles, norms of pre-Soviet socially oriented practices ensure the viability and socially oriented mission of domestic vocational educational institutions.

Keywords: zemstvo charity, social work, social support, social security, vocational education, vocational school.

Подано до редакиії 14.02.2021

UDC 373.2:37.018.1-053.4]-047.37

DOI: https://doi.org/10.24195/2414-4665-2021-1-10

\author{
Abdülkadir Kabadayı, \\ PhD (Candidate of Pedagogical Sciences), associate professor, Dr., \\ A. K. Faculty of Education, Department of Basic Education, \\ Necmettin Erbakan University, Meram Kampüsü, Meram Yeniyol, \\ 42090, Meram Yeniyol, Konya, Turkey, \\ Emine Bilge Altunok, \\ M. A. (Master of Pedagogical Sciences), \\ Institution of Educational Sciences, \\ Necmettin Erbakan University, Meram Kampüsü, Meram Yeniyol, \\ 42090, Meram Yeniyol, Konya, Turkey
}

\title{
INVESTIGATION OF THE RELATIONSHIP BETWEEN PARENTAL STYLES WITH COMMUNICATION SKILLS OF PRESCHOOL CHILDREN ${ }^{1}$
}

It can be stated that the relationships that parents have with their children in the preschool period have a great impact on their future social-emotional lives and a significant part of learning takes place in the preschool period. Considering those parents' attitudes during child-rearing may affect the child's development and interpersonal relationships; this study aims to examine the relationship between parental attitudes and communication skills of 36-72 monthold children attending preschool education institutions. This research: parents' attitudes concerning reveal the relationship between preschool children's communication skills, preschool in Turkey period in terms of the lack of a sufficient number of working children about the communication skills, parents and educators; it is thought to be important in terms of providing a different perspective and contributing to the development of children's communication skills and drawing their attention to this issue, and also in terms of guiding researchers in future studies on the subject. The research was conducted using the relational scanning model. The population of this research consists of 36-72 months old children attending pre-school education institutions in Elazlğ city center and Diyarbakur central districts in the 2017-2018 academic year, and parents of 36-72 months old children. The sample of the study consisted of 300 children and 320 parents randomly selected from the universe. In the research, the "Parental Attitudes Questionnaire" and "Communication Skills Scale" were used. The Parental Attitudes Determination Questionnaire consists of four parental attitudes (oppressive-authoritarian, protective, indifferent-carefree, democratic). The Communication Skills Scale consists of four communication skills (verbal communication, avoiding communication barriers, and communication with courtesy content, non-verbal communication). The data obtained were analyzed with SPSS 22 program. In the statistical evaluation, firstly, a normality test was applied to the subscales of the "Parental Attitudes Determination Questionnaire" and the "Communication Skills Scale". Since " $p<0.05$ " in all communication skills subscales and all parental attitudes subscales, it was accepted that they did not show a normal distribution. Thus, Spearman Correlation was applied to test whether there was a significant relationship between parent attitudes and communication skills. According to the results of the research it is observed that parents adopt "Democratic Attitude" the most and "Verbal Communication Skills" are used the most by preschool children. No significant relationship was found between oppressiveauthoritarian, indifferent-carefree, and democratic parental attitudes and subscales of communication skills. Only a low level of negative correlation was found between the protective parental style and the verbal communication skills subscale. According to the results of the study, parents and educators can be trained on parent attitudes and communication skills. Educators can support the development of children with low communication skills with activities that will showcase their social skills and allow them to express themselves. To parents who show a protective attitude; children can be helped to behave in a way that supports their verbal communication skills, affects the personality development of

${ }^{1}$ This study is the part of M.A. dissertation completed in Necmettin Erbakan University, in 2019

Science and Education, 2021, Issue 1 
the child positively, and allows them to develop a personality structure independent of others. This research was conducted in Elâzlğ and Diyarbaktr provinces. Turkey will be held in the west of the province or be provided with a contribution to the results of the research will be done with a much larger sample group. The relationship between the communication skills of preschool children and an area different from the parent attitudes can be examined.

Keywords: Preschool, parental styles, communication skills, authoritarian, indifferent, democratic.

\section{Introduction and the current state of the research problem}

The life of a preschool child can be shaped according to whether his needs are met or not. Parents should meet the needs of the child and be able to equip the child with basic skills. Preschool children can communicate better and healthily thanks to the skills they will gain in social development.

Parents may adopt different attitudes while raising their children and may have different effects on their children's development. Parental attitudes can generally be classified as indifferent parental attitude, overprotective parental attitude, authoritarian parental attitude, and democratic parental attitude.

The indifferent parental style that does not care about their children, behaves indifferently, ignores their social-emotional needs, shows little love, causes them to see negative behaviors in their children. The child sees the rules as unnecessary in the indifferent style that the parents mostly give their children rights that they do not restrict (Özyürek ve Tezel Şahin, 2012: 39).

Overprotective mother; she feeds her child with her baby-like hands and worries unnecessarily about her. Such an approach to the child gives the message that you do not know, you cannot succeed, you are small, you cannot solve your problems alone (Çağdaş, 1997: 104).

While Baumrind (1966) describes authoritarian parents in one of his researches; he expressed them as people who expect children to obey their rules completely and impose punishments on children when they do not obey the rules. He also stated that these parents do not consult with their children much and they expect their children to accept everything they say unconditionally.

The democratic attitude, on the other hand, goes beyond the direct control of the child by setting prohibitions and rules, explaining the reason for the rules and supporting them with other parenting strategies, helping children to obey the rules. It is necessary to ensure that these rules are followed in the formation of healthy personality structures. It can be stated that people should know and use their communication skills effectively so that they can establish healthy interpersonal communication, understand each other and get along well with each other. It can be said that especially in the preschool period when the foundations of all skills are laid, it is necessary to teach communication skills to children and to use communication skills inappropriate situations.

Communication is influencing individuals by exchanging feelings, thoughts, information, and news. For communication to occur, there is a need for a source, a target, a message, a way that this message can go, an environment for the communication to take place, and a tool that can deliver this message (Topbaş et al., 2001: 3).
Communication skills can be defined as learned behaviors based on empathy and respect, being able to convey their feelings and thoughts to the other person with "I language" and being able to listen effectively, by creating consistency between verbal and non-verbal messages, enabling the individual to establish satisfactory relationships with others and facilitate the life of the individual in society (Yüksel Şahin, 2009: 233).

Communication skills required for effective communication can be classified as follows: Verbal communication (speaking), listening, self-knowledge and selfdisclosure, empathy, non-verbal communication (body language), effective response skills.

Listening to understand the feelings and feelings of the person in communication makes the person feel understood. It takes empathic listening to fully understand the feelings and thoughts of the other person and express this to him (Gürüz ve Temel Eğinli, 2011: 271).

It can be said that the skill of empathy should be gained to children at an early age because "Do not do the behavior you do not want to do with yourself to another living thing!" If such an understanding is adopted especially to pre-school children; they can grow up as individuals who show compassion to animals, do not inflict violence on their wives, are understanding towards those who are in a difficult situation, respectful of nature and living things, tolerant of other ideas, and approach their children with interest and love.

In nonverbal communication, individuals convey some messages to each other without writing and speaking. In this type of communication, what people say does not matter, what they do is at the forefront (Dökmen, 2002: 28). The elements that make non-verbal communication are generally; glances and eye contact, facial expressions, hand-arm and body movements (gestures), head movements, touch, space, and distance.

Researchers have dealt with the factors that hinder the communication process differently, and thus many reasons that negatively affect and disrupt communication emerge.

According to Gordon (2003: 39), communication barriers between parent and child are giving orders, warning, threatening, giving advice, judging and criticizing, ridiculing, distracting, being offended, expressing praise, suggesting solutions, entering into logical arguments, suggesting and consoling, and to ask questions.

The role of parents in developing children's communication skills is great. Parents should allow their children to express themselves and allow the child to perceive him/herself as an "individual" and gain selfconfidence. Unconditional acceptance, empathy, active listening, and use of self-language is essential for effective communication (MEB, 2013: 46). 
The attitudes and behaviors of the parents may affect the child's development, social adaptation and interpersonal relations and that there is not enough research done on communication skills in the preschool period, this study was deemed necessary. The question of the relationship between parental attitudes and preschool children's communication skills is the problem of the study.

\section{Aim and tasks}

The study aims to examine the relationship between parental attitudes and communication skills of 36-72 month-old children attending preschool education institutions. According to this general-purpose and sub-goals, answers to the following questions were sought:

Is there a relationship between parental attitudes and preschool children's communication skills?

a. Is there a relationship between oppressiveauthoritarian parental attitudes and the communication skills of preschool children?

b. Is there a relationship between protective parental attitudes and preschool children's communication skills?

c. Is there a relationship between apathetic-carefree parent attitudes and the communication skills of preschool children?

d. Is there a relationship between democratic parental attitudes and preschool children's communication skills?

\section{Research methods}

This study, which examines the relationship between parental attitudes and communication skills of preschool children, was carried out with the survey model.

Survey models are research approaches that aim to describe a past or present situation as it exists. The event, individual, or sample, universe to the research is tried to be defined in its conditions and as it is, without changing it or making an effort to influence it (Karasar, 2013: 77).

The population of the study consists of the parents of 36-72-month-old children and 36-72-month-old children attending pre-school education institutions in Elazığ and Diyarbakır in the 2017-2018 academic year.

The sample of the research consists of randomly selected 300 children of 36-72 months and 320 parents with 36-72 months old children studying in pre-school education institutions permitted for study in Elazı $\breve{g}$ city center and central districts of Diyarbakır.

To collect research data the "Parent Attitudes Determination Questionnaire" prepared by Günalp (2007) and for which permission was obtained and the "Communication Skills Scale" prepared by Görgülü (2009) and for which permission was obtained were used.

Parents who made up the sample group to collect their data filled in the "Parental Attitudes Determination Questionnaire". The "Communication Skills Scale" was completed on behalf of the preschool teachers, who worked in the pre-school education institution and had known their students in the sample group for at least 5 months.

The data obtained from the questionnaires and scales used in the study were analyzed using the SPSS 22 program according to the necessary statistical processes comprising Mean Scores and Kolmogorov-Smirnov, Shapiro-Wilk.

The distribution of the mean scores of the subscales of the "Parent Attitudes Determination Questionnaire" filled by the parents in the sample group and the distribution of the mean scores of the subscales of the "Communication Skills Scale" filled by the teachers for their students in the sample group are shown in the tables below.

\begin{tabular}{|c|c|c|c|}
\hline & $\begin{array}{l}\text { Average and } \\
\text { Standard Devi- } \\
\text { ation }\end{array}$ & Minimum Score & Maximum Score \\
\hline $\begin{array}{l}\text { Oppressive- } \\
\text { Authoritarian Paren- } \\
\text { tal Style }\end{array}$ & $4,68^{25,09 \pm}$ & 15,00 & 41,00 \\
\hline $\begin{array}{l}\text { Protective Parent } \\
\text { Style }\end{array}$ & $4,48^{29,31} \pm$ & 18,00 & 41,00 \\
\hline $\begin{array}{l}\text { Uninterested- } \\
\text { Carefree Parental } \\
\text { Style }\end{array}$ & $3,78^{21,51 \pm}$ & 15,00 & 38,00 \\
\hline $\begin{array}{l}\text { Democratic Parental } \\
\text { Style }\end{array}$ & $2,89^{40,78 \pm}$ & 30,00 & 45,00 \\
\hline
\end{tabular}

Table 1

Average and

Standard Devi- Minimum Score Maximum Score

25,09

Accordingly, looking at Table 1, looking at these average values, it is seen that the most adopted style of parents is "Democratic Attitude".
Accordingly, looking at Table 2, it is seen that preschool children mostly used "Verbal Communication Skills" by looking at these average values. 
Mean Scores of Sub-Scales of the Communication Skills Scale

Table 2

\begin{tabular}{lcrlll}
\hline & \multicolumn{3}{c}{ Mean Scores of Sub-Scales of the Communication Skills Scale } \\
\hline & $\begin{array}{c}\text { Average } \\
\text { Standard } \\
\text { tion }\end{array}$ & $\begin{array}{c}\text { and } \\
\text { Devia- }\end{array}$ & Minimum Score & Maximum Score \\
\hline $\begin{array}{l}\text { Verbal } \\
\text { Skills }\end{array}$ & Communication & $34,47 \pm 6,92$ & 11,00 & 45,00 \\
\hline $\begin{array}{l}\text { Avoiding } \\
\text { Barriers }\end{array}$ & Communication & $18,09 \pm 4,10$ & 6,00 & 25,00 \\
\hline $\begin{array}{l}\text { Courtesy } \\
\text { Skills }\end{array}$ & Communication & $22,73 \pm 5,02$ & 8,00 & 30,00 \\
\hline $\begin{array}{l}\text { Non-Verbal } \\
\text { tion Skills }\end{array}$ & Communica- & $11,65 \pm 2,85$ & 3,00 & 15,00 \\
\hline
\end{tabular}

To determine the type of tests to be applied in SPSS; the normality test results of the mean scores of the subscales of the Communication Skills Scale and the mean scores of the subscales of the Questionnaire for Determining Parental Attitudes are shown below in tables:

Normality Test of Sub-Scales of Communication Skills Scale Mean Scores

Table 3

\begin{tabular}{|c|c|c|c|c|c|c|}
\hline & \multicolumn{3}{|c|}{ Kolmogorov-Smirnov } & \multicolumn{3}{|c|}{ Shapiro-Wilk } \\
\hline & Statistic & df & Sig. & Statistic & df & Sig. \\
\hline Verbal & & & & & & \\
\hline $\begin{array}{l}\text { Communication } \\
\text { Skills }\end{array}$ & ,096 & 300 &, 000 & ,096 & 300 &, 000 \\
\hline $\begin{array}{l}\text { Avoiding Communica- } \\
\text { tion Barriers }\end{array}$ &, 095 & 300 &, 000 &, 972 & 300 & 000 \\
\hline $\begin{array}{l}\text { Courtesy Communi- } \\
\text { cation Skills }\end{array}$ & ,074 & 300 & ,000 & ,962 & 300 &, 000 \\
\hline $\begin{array}{l}\text { Non-Verbal Com- } \\
\text { munication Skills }\end{array}$ &, 155 & 300 &, 000 & ,917 & 300 & ,000 \\
\hline
\end{tabular}

$(\mathrm{p}>.05)$

As a result of the normality test conducted to determine whether the mean scores of the Communication Skills Scale subscales show normal distribution, it is accepted that the data are normally distributed if the Kol-
mogorov-Smirnov value is $\mathrm{p}>.05$ (Büyüköztürk, 2013). However, as seen in Table 3, it was observed that the data were not distributed normally, since all four sub-skills were "p <.05" ( $=.000)$.

Normality Test of the Mean Scores of the Subscales of the Parental Attitudes Questionnaire

\begin{tabular}{|c|c|c|c|c|c|c|}
\hline & \multicolumn{3}{|c|}{ Kolmogorov-Smirnov } & \multicolumn{3}{|c|}{ Shapiro-Wilk } \\
\hline & Statistic & df & Sig. & Statistic & df & Sig. \\
\hline $\begin{array}{l}\text { Oppressive-Authorian } \\
\text { Parental } \\
\text { Style }\end{array}$ & ,088 & 320 & ,000 & 981 & 320 & 000, \\
\hline $\begin{array}{l}\text { Protective } \\
\text { Parent } \\
\text { Style }\end{array}$ & ,058 & 320 & ,011 & 992 & 320 & 089, \\
\hline $\begin{array}{l}\text { Uninterested- } \\
\text { Carefree } \\
\text { Parental Style }\end{array}$ & ,091 & 320 & ,000 & 965 & 320 & 000, \\
\hline $\begin{array}{l}\text { Democratic Parental } \\
\text { Style }\end{array}$ & ,134 & 320 & ,000, & 939, & 320 & 000 \\
\hline
\end{tabular}

$(\mathrm{p}>.05)$ 
As a result of the normality test conducted to determine whether the mean scores obtained from the subscales of the "Parent Attitudes Determination Questionnaire" show normal distribution, it is accepted that the data are normally distributed if the Kolmogorov-Smirnov value is $\mathrm{p}>.05$ (Büyüköztürk, 2013). However, as seen in Table 4 , it was observed that the data were not distributed normally, since "p <.05" was found in a total of four subattitudes.

\section{Results and Discussion}

Since the mean scores of the subscales of the "Parent Attitudes Determination Questionnaire" and the subscales of the "Communication Skills Scale" did not show a normal distribution, the relationship between them is shown in the tables below by applying Spearman Correlation. The level of significance in the analysis was taken as .05 .
The correlation coefficient, a relationship between 0.70-1.00 can be defined as high, between 0.70-0.30 as a medium, and between $0.30-0.00$ as a low level (Büyüköztürk, 2013). According to the level of this correlation coefficient, the findings of the analyzes were interpreted.

According to the Spearman Correlation Analysis result in Table 5: no statistically significant relationship was found between the oppressive-authoritarian parental style subscale mean scores and the verbal communication skills subscale mean scores $(\mathrm{r}=-.085, \mathrm{p}>.05)$.

There was no statistically significant relationship between the mean scores of the oppressive-authoritarian parental style subscale and the subscale of avoiding communication barriers $(r=.070, \mathrm{p}>.05)$.

Table 5

Spearman Correlation Analysis Results Between the Oppressive-Authoritative Parental style and Communication Skills

\begin{tabular}{llllll} 
& \multicolumn{5}{c}{ tion Skills } \\
& $\begin{array}{l}\text { Verbal } \\
\text { Communication } \\
\text { Skills }\end{array}$ & $\begin{array}{l}\text { Avoiding } \\
\text { Communication } \\
\text { Barriers }\end{array}$ & $\begin{array}{l}\text { Courtesy } \\
\text { Communication } \\
\text { Skills }\end{array}$ & $\begin{array}{l}\text { Non-Verbal } \\
\text { Communication } \\
\text { Skills }\end{array}$ \\
\cline { 2 - 5 } $\begin{array}{l}\text { Oppressive- } \\
\text { Auethorian } \\
\begin{array}{l}\text { Parntal } \\
\text { style }\end{array}\end{array}$ & $\mathbf{r}$ &,- 085 &, 070 &,- 033 &, 056 \\
\cline { 2 - 6 } & $\mathbf{p}$ &, 142 &, 226 &, 568 &, 330 \\
\hline
\end{tabular}

There was no statistically significant relationship between the oppressive-authoritarian parental style subscale mean scores and the communication skills subscale with courtesy content subscale mean scores $(r=-.033$, $\mathrm{p}>.05)$.
No statistically significant relationship was found between the oppressive-authoritarian parental style subscale mean scores and non-verbal communication skills subscale mean scores $(r=-.056, \mathrm{p}>.05)$.

Table 6

Spearman's Correlation Analysis Results Between Protective Parent style and Communication Skills

\begin{tabular}{|c|c|c|c|c|c|}
\hline & & $\begin{array}{l}\text { Verbal } \\
\text { Communication } \\
\text { Skills }\end{array}$ & $\begin{array}{l}\text { Avoiding } \\
\text { Communication } \\
\text { Barriers }\end{array}$ & $\begin{array}{l}\text { Courtesy } \\
\text { Communication } \\
\text { Skills }\end{array}$ & $\begin{array}{l}\text { Non-Verbal } \\
\text { Communication } \\
\text { Skills }\end{array}$ \\
\hline \multirow{2}{*}{$\begin{array}{l}\text { Protective } \\
\text { Parent Style }\end{array}$} & $\mathbf{r}$ &,- 114 & ,013 &,- 089 &,- 060 \\
\hline & $\mathbf{p}$ & ,048 & 819 &, 123 & ,303 \\
\hline
\end{tabular}

$\mathrm{p}<0,05$

According to the Spearman Correlation Analysis result in Table 6: a low statistically negative correlation was found between the mean scores of the protective parental style subscale and the verbal communication skills subscale ( $\mathrm{r}$ $=-.114, \mathrm{p}<.05)$.

There was no statistically significant relationship between the mean scores of the protective parental style subscale and the subscale of avoiding communication barriers $(r=.013, \mathrm{p}>.05)$.

There was no statistically significant relationship between the mean scores of the protective parental style subscale and the communication skills subscale with courtesy content $(r=-.089, \mathrm{p}>.05)$. 
There was no statistically significant relationship between the mean scores of the protective parental style subscale and the non-verbal communication skills subscale mean scores $(r=-.060, \mathrm{p}>.05)$.

Table 7

Spearman Correlation Analysis Results Between Indifferent-Carefree Parent style and Communication Skills

$\begin{array}{llll}\text { Verbal } & \text { Avoiding } & \text { Courtesy } & \text { Non-Verbal } \\ \text { Communication } & \text { Communication } & \text { Communication } & \text { Communication } \\ \text { Skills } & \text { Barriers } & \text { Skills } & \text { Skills }\end{array}$

\begin{tabular}{lccccc}
\hline & & & & \\
$\begin{array}{l}\text { Uninterested- } \\
\text { Carefree Parental } \\
\text { Style }\end{array}$ & $\mathbf{r}$ &,- 105 &, 005 &,- 020 &,- 068 \\
\cline { 2 - 6 } & $\mathbf{p}$ &, 070 &, 928 &, 736 &, 241
\end{tabular}

$\mathrm{p}<0,05$

According to the Spearman Correlation Analysis result in Table 7: there was no statistically significant relationship between the mean scores of the indifferentcarefree parental style subscale and the verbal communication skills subscale mean scores $(r=-.105, \mathrm{p}>.05)$.

There was no statistically significant relationship between the mean scores of the apathetic-carefree parental style subscale and the subscale of avoiding communication barriers $(r=.005, \mathrm{p}>.05)$.
No statistically significant relationship was found between the mean scores of the indifferent-carefree parental style subscale and the communication skills subscale with courtesy content $(\mathrm{r}=-.020, \mathrm{p}>.05)$.

No statistically significant correlation was found between the mean scores of the indifferent-carefree parental style subscale and the non-verbal communication skills subscale $(\mathrm{r}=-.068, \mathrm{p}>.05)$.

Spearman Correlation Analysis Findings between Democratic Parental style and Communication Skills

\begin{tabular}{llllll}
\multicolumn{6}{c}{ Spearman Correlation Analysis Findings } \\
\cline { 2 - 5 } & $\begin{array}{l}\text { Verbal } \\
\text { Communication } \\
\text { Skills }\end{array}$ & $\begin{array}{l}\text { Avoiding } \\
\text { Communication } \\
\text { Barriers }\end{array}$ & $\begin{array}{l}\text { Courtesy } \\
\text { Communication } \\
\text { Skills }\end{array}$ & $\begin{array}{l}\text { Non-Verbal } \\
\text { Communication } \\
\text { Skills }\end{array}$ \\
\hline $\begin{array}{l}\text { Democratic } \\
\text { Parental Style }\end{array}$ & $\mathbf{r}$ &,- 026 &, 080 &, 010 &, 022 \\
\cline { 2 - 6 } & $\mathbf{p}$ &, 660 &, 166 &, 860 &, 703 \\
\hline
\end{tabular}

$\mathrm{p}<0,05$

According to the Spearman Correlation Analysis result in Table 8, there was no statistically significant relationship between the mean scores of the democratic parental style subscale and the verbal communication skills subscale mean scores $(r=-.026, \mathrm{p}>.05)$.

There was no statistically significant relationship between the mean scores of the democratic parental style subscale and the subscale of avoiding communication barriers $(r=.080, \mathrm{p}>.05)$.

There was no statistically significant relationship between the mean scores of the democratic parental style subscale and the communication skills subscale with courtesy content $(r=.010, p>.05)$.

No statistically significant relationship was found between the mean scores of the democratic parental style subscale and the non-verbal communication skills subscale mean scores $(r=.022, p>.05)$.

\section{Conclusion}

No statistically significant relationship was found between the oppressive-authoritarian parental style subscale mean scores and verbal communication skills, avoiding communication barriers, communication skills with courtesy content, and non-verbal communication skills subscale mean scores.

Günalp (2007) found a significant negative correlation between the oppressive-authoritarian parental style and the development of children's self-confidence. According to this, she stated that as the level of parents' adoption of the oppressive-authoritarian parental style increases, the self-confidence of children decreases, that is, the oppressive-authoritarian parental style negatively affects the self-confidence of the 5-6 age group children attending preschool education institutions.

According to the results of a study conducted by Gülay and Önder (2011), the social-emotional adjustment levels of the children differ according to the attitudes of the mothers. They found that the social-emotional adjustment levels of the children of authoritarian and permissive 
mothers were lower than those who were not authoritarian and permissive.

In a study conducted by Ogelman et al. (2013) a significant negative correlation was found between the authoritarian attitudes of mothers and their children's social skills and school adjustment. As the authoritarian attitudes of mothers increase, children's social skills realization and school adjustment levels decrease; they stated that as the authoritarian style decreases, the level of social skills realization and school adjustment increases.

As a result of Ünal Güçlü (2015) research she stated that there was no relationship between oppressive parental style and child behavior.

A statistically significant relationship was not found between the mean scores of the protective parental style subscale and the averages of the subscales of communication skills including avoidance of communication barriers, courtesy content, and non-verbal communication skills. However, there is an inversely proportional relationship between the mean scores of the protective parental style subscale and the verbal communication skills subscale mean scores.

As a result of Günalp (2007) research, a significant negative relationship between protective parental style and the development of children's self-confidence were found. According to this she stated that as the level of adopting protective parental style increases, children's self-confidence decreases, that is, protective parental style negatively affects the self-confidence of 5-6-year-old children attending preschool education institutions.

As a result of Ünal Güçlü (2015) research there was no relationship between protective parental style and child behavior.

No statistically significant relationship was found between the mean scores of the indifferent-carefree parent style subscale and the mean scores of verbal communication skills, avoiding communication barriers, communication skills with courtesy content, and non-verbal communication skills subscales.

As a result of Günalp (2007) research she found a significant negative correlation between apatheticindifferent parental style and the development of children's self-confidence. According to this, she stated that as the level of adoption of the indifferent-indifferent parent style increases, the self-confidence of children decreases, that is, the style of indifferent parents negatively affects the self-confidence of 5-6-year-old children attending preschool education institutions.

In a study conducted by Ogelman et al. (2013) a significant negative correlation was found between the permissive attitudes of mothers and their children's social skills and adaptation to school. As the permissive attitudes of mothers increase, children's social skills realization and school adjustment levels decrease; as the apathetic style decreases, it is seen that the levels of social skills realization and school adjustment increase.

As a result of Ünal Güçlü (2015) research she stated that there was no relationship between indifferent parental style and child behavior.

No statistically significant relationship was found between the mean scores of the democratic parental style subscale and the verbal communication skills, avoiding communication barriers, communication skills with courtesy content, and non-verbal communication skills subscales.

Günalp (2007) stated that there is a positive significant relationship between democratic parental style and the development of children's self-confidence. According to this, she stated that as the level of adoption of democratic style increases, the self-confidence of children will increase, that is, the democratic parental style positively affects the self-confidence of 5-6-year-old children attending preschool education institutions.

In a study conducted by Ogelman et al. (2013) there was a significant positive correlation between mothers' democratic attitudes and their children's social skills and school adaptation. As the mothers' democratic attitudes increase, children's social skills realization and school adjustment levels increase; it is seen that as the democratic style decreases, the level of social skills realization and school adaptation decreases.

And1 (2014) wanted to see whether the social behavior control, social adaptation, and social competence levels of preschool children evaluated by the teacher differ according to parent child-rearing attitudes and family life; it was concluded that there was no significant difference between parents' attitudes and social competence and negative social behaviors of the child.

According to the results of a study by Gözübüyük (2015) it is seen that there is a positive and direct relationship between parents' child-rearing style and self-control, and there are indirect relationships between self-control and behavioral problems.

As a result of Ünal Güçlü' research (2015), she stated that there is an inverse relationship between democratic family style and child behavior, but it is not statistically significant.

As a result no significant relationship was found between oppressive-authoritarian, indifferent-carefree, and democratic parents' attitudes and communication skills of 36-72 month-old children attending preschool education institutions. Only a low level of negative correlation was found between foster parenting attitudes and preschool children's verbal communication skills. As the mean scores of protective parental attitudes increase, the mean scores of verbal communication skills decrease.

Suggestions:

a) Parents and educators can be trained on parent attitudes and communication skills.

b) Educators can support the development of children with low communication skills with activities that will showcase their social skills and allow them to express themselves.

c) Parents who display a protective attitude; affect the personality development of the child positively, and allow them to develop a personality structure independent of others.

d) This research was conducted in Elâzığ and Diyarbakir provinces. Other researches will be held in the west of the provinces or be provided with the results with a 
much larger sample group.

e) The relationship between the communication

\section{References}

1. And1, F.T. (2014). Okul Öncesi Çocuklarda Ögretmen Tarafindan Ölçülen Sosyal Davranış Denetimi, Sosyal Uyum ve Sosyal Yeterlilik Düzeylerinin, Ebeveyn Çocuk Yetiştirme Tutumlarl ile Ilişsisinin Incelenmesi. Haliç Üniversitesi Sosyal Bilimler Enstitüsü, Yüksek Lisans Tezi. İstanbul.

2. Baumrind, D. (1966). Effects of Authoritative Parental Control on Child Behavior. Child Development 37 (4), 887-907.

3. Büyüköztürk, Ş. (2013). Sosyal Bilimler İçin Veri Analizi El Kitabl. Ankara: Pegem Akademi.

4. Can, G. (2003). Bir kurum ve bir sistem olarak aile. (Editör: Sibel Türküm). Anne Baba Eğitimi. Eskişehir: Anadolu Üniversitesi Yayınları, 1-22.

5. Çağdaş, A. (1997). İletişim Dilinin 4-5 Yaş Çocuklarının Sosyal Gelişimine Etkileri. Selçuk Üniversitesi Sosyal Bilimler Enstitüsü, Doktora Tezi. Konya.

6. Dökmen, Ü. (2002). Iletişsim Çatışmaları ve Empati (18. Bask1). İstanbul: Sistem Yayıncılık.

7. Gordon, T. (2003). Aile İletişim Dili. (Çeviren: Emel Aksay). İstanbul: Sistem Yayıncılık.

8. Görgülü, F. (2009). Drama Destekli Kubaşık Öğrenme Etkinliklerinin Okul Öncesi 5-6 Yaş Çocuklarının Iletişim Becerilerine Etkisi. Adnan Menderes Üniversitesi Sosyal Bilimler Enstitüsü, Yüksek Lisans Tezi. Aydın.

9. Gözübüyük, N. (2015). Okul Öncesi Dönem Çocuklarında Davranış Sorunlarının Anne-Baba Tutumu ve Öz-Kontrol ile İlişkisinin Incelenmesi. Adnan Menderes Üniversitesi Sosyal Bilimler Enstitüsü, Yüksek Lisans Tezi. Aydın.

10. Gülay, H. ve Önder, A. (2011). Annelerinin tutumlarına göre 5-6 yaş çocuklarının sosyal-duygusal uyum düzeyleri. Celal Bayar Üniversitesi Eğitim Fakültesi Dergisi 1 (1), 89-105. skills of preschool children and an area different from the parents' attitudes can be examined.

11. Günalp, A. (2007). Farklı Anne Baba Tutumlarının Okul Öncesi Eğitim Çağındaki Çocukların Özgüven Duygusunun Gelişimine Etkisi (Aksaray Ili Örneği). Selçuk Üniversitesi Sosyal Bilimler Enstitüsü, Yüksek Lisans Tezi. Konya.

12. Gürüz, D. ve Temel Eğinli, A. (2011). Kişiler Arası Iletişim, Bilgiler-Etkiler-Engeller (2. Bask1). İstanbul: Nobel Yayınları.

13. Karasar, N. (2013). Bilimsel Araştırma Yöntemi (25. Bask1). Ankara: Nobel Yayın Dağıtım.

14. Kayış, A. (2010). Güvenilirlik analizi. (Editör: Şeref Kalaycı). SPSS Uygulamalı Çok Değişkenli İstatistik Teknikleri. Ankara: Asil Yayın Dağıtım, 405.

15. MEB (Millî Eğitim Bakanlığı). (2013). 0-36 Ay Çocukları İçin Eğitim Programı ile Bütünleştirilmiş Aile Destek Eğitim Rehberi (EBADER) Ĕgitimci Kitabl. Ankara: MEB.

16. Ogelman, H.G., Önder, A., Seçer, Z. ve Erten, H. (2013). Anne tutumlarının 5-6 yaş çocuklarının sosyal becerilerini ve okula uyumlarını yordayıcı etkisi. Selçuk Üniversitesi Sosyal Bilimler Enstitüsü Dergisi 29, 143152.

17. Özyürek, A. ve Tezel Şahin, F. (2012). Annebaba olmak ve anne-babaların çocuk yetiștirme tutumları. (Editör: Tülin Güler). Anne Baba Eğitimi. Ankara: Pegem Akademi. 35-52.

18. Topbaş, S. (2001). İletişim, dil, konuşma: temel kavramlar. (Editör: Seyhun Topbaş). Çocukta Dil ve Kavram Gelişimi. Eskişehir: Anadolu Üniversitesi Yayınlar1, 1-22.

19. Ünal Güçlü, G. (2015). Okul Öncesi Dönemdeki Çocukların Davranışlarıyla Anne Baba Tutumları Arasındaki İlişkinin Incelenmesi, Necmettin Erbakan Üniversitesi Eğitim Bilimleri Enstitüsü, Yüksek Lisans Tezi. Konya.

20. Yüksel Şahin, F. (2009). Kişiler arası ilişkiler ve iletişim becerileri. (Editör: Haluk Yavuzer). Evlilik Okulu. İstanbul: Remzi Kitabevi, 230-255.
Абдулкадір Кабадай, кандидат педагогічних наук, доиент кафедри загальної освіти, Університет Некметтіна Ербакан, Кампус Мерам, 42090, Мерам Енійол, м. Конья, Туреччина,

Еміне Більге Алтунок, магістр Інституту педагогічних наук, Університет Некметтіна Ербакан, Кампус Мерам, 42090, Мерам Енійол, м. Конья, Туреччина

\section{ДОСЛІДЖЕННЯ ВЗАЕМОЗВ'ЯЗКУ СТИЛЕЙ БАТЬКІВСЬКОГО ВИХОВАННЯ 3 КОМУНІКАТИВНИМИ НАВИЧКАМИ ДІТЕЙ ДОШКІЛЬНОГО ВІКУ}

Встановлено, що стосунки батьків зі своїми дітьми в дошкільний період мають великий вплив на їхнє подальше соціально-емоційне життя і значна частина навчання відбувається саме в цьому періоді. Врахування ставлення батьків під час виховання дитини може вплинути на ії розвиток та міжособистісні стосунки. Мета дослідити взаємозв'язок між ставленням батьків та комунікативними навичками дітей 36-72 місяців, які відвідують дошкільні навчальні заклади. Досліджено ставлення батьків щодо виявлення взаємозв'язку між комуні- 
кативними навичками дітей дошкільного віку. Вважається важливою думка про надання різного бачення проблеми, сприяння розвитку комунікативних навичок дітей та залучення їхньої уваги до цієї проблеми, а також 3 огляду керівництва дослідників у майбутніх дослідженнях з цього питання. Дослідження проводили з використанням реляційної моделі. Учасниками цього дослідження виступали батьки та їх діти віком 36-72 місяців, які відвідують дошкільні навчальні заклади в центрі міста Елязиг та центральних районах Діярбакиру в 2017-2018 навчальних роках. Вибірка дослідження складалася з випадково вибраних 300 дітей та 320 батьків. У дослідженні були використані "Опитувальник визначення батьківського ставлення" та "Шкала комунікативних навичок". Вказаний опитувальник складається з чотирьох стилей батьківського виховання (суворо-авторитарний, опікунський, індиферентно-безтурботний, демократичний). Шкала складається 3 чотирьох комунікативних навичок (вербальне спілкування, уникання комунікативних бар'єрів та ввічливе спілкування, невербальне спілкування). Отримані дані аналізували за допомогою програми SPSS 22. У статистичній оцінці, перш за все, критерії нормальності застосовували для підшкал "Опитувальника визначення батьківського ставлення" та "Шкали комунікативних навичок". Оскільки прослідковувалося значення «р $<0,05 »$ у всіх підшкалах комунікативних навичок та всіх підшкалах батьківського ставлення, прийнято, що вони не демонструють нормального розподілу. Таким чином, кореляція Спірмена була застосована для перевірки існування суттєвого взаємозв'язку між ставленням батьків та комунікативними навичками. За результатами дослідження виявлено, що батьки найбільше сприймають "демократичне ставлення", а "навички вербального спілкування" найбільше використовують діти дошкільного віку. Не було знайдено жодного значущого взаємозв'язку між суворо-авторитарним, індиферентно-безтурботним, демократичним ставленням батьків та підшкалами комунікативних навичок. Виявлено лише низький рівень негативної кореляції між опікунським батьківським стилем та підшкалою навичок вербальної комунікації. Згідно з результатами дослідження, батьки та вихователі можуть навчитися правильному ставленню до дітей та комунікативним навичкам. Вихователі можуть підтримати розвиток дітей з низькими комунікативними навичками за допомогою діяльності, яка продемонструє їх соціальні навички та дозволять їм проявити себе. Дітям батьків, які виявляють опікунський стиль виховання, можна допомогти поводитися таким чином, щоб підтримувати їхні навички вербального спілкування, позитивно впливати на розвиток особистості дитини та дозволяти ім розвивати структуру особистості. Це дослідження було проведено в провінціях Елязиг та Діярбакир.

Ключові слова: дошкільний навчальний заклад, батьківські стилі, комунікативні навички, авторитарний, індиферентний, демократичний. 